\title{
The Determinants of the Capital Structure: Evidence from Jordanian Industrial Companies
}

\author{
Husni Ali Khrawish and Ali Husni Ali Khraiwesh* \\ College Business Administration (CBA) \\ Sabbatical Year, 2007-2008, \\ Jeddah, Saudi Arabia, and *MBA. Finance, \\ Coventry Business School, Coventry University UK \\ khrawish@hu.edu.jo_Ali.Khraiwesh@gmail.com
}

(Received 01.03.1429H., and Accepted 18.06.1429H.)

Abstract. This study examined the capital structure of listed industrial companies on Amman Stock Exchange (ASE) over the period (20012005). The findings of this study contribute towards a better understanding of financing behaviour in Jordanian industrial companies. Hypotheses, based on comparing the relationships between Leverage ratio (Lev 1), LTD/TD (Long-term debts/total debts) and five explanatory variables that represent size, tangibility, profitability, long-term debt and short-term debt. To test those relationships regression analysis for Leverage ratio (Lev 1) and $\frac{L T D}{T D}$ model was used to explain determinants of the capital structure of Jordanian industrial companies on the time period (2001 - 2005).

There was a significant positive relationship between leverage ratio (Lev 1) and size (TA), Tangibility (Tang), long-term debt (LTD) and short-term debt (STD) and there was a significant negative relationship between leverage ratio and Profitability of the firm.

In other words, the results of this study showed that a significant positive relationship between LTD/TD and size (TA), Tangibility (Tang), and long-term debt (LTD) and there was a negative relationship between LTD/TD and short-term debt of the firm.

Also, the results showed that Total assets, Tangibility, Long-term debt, had a positive correlation with LTD/TD. While, short-term debt had a negative correlation with LTD/TD. 
As well as, Jordanian industrial companies are depending on equity for financing their investments, where, the equity of Jordanian industrial companies represents about $(70 \%)$ from their total finance. Despite the fact that this correlation matrix ignores joint effects of more than one variable on leverage, the Long-term debt, and Shortterm debt are positively related to Tangibility and Total assets. Profitability has a negative correlation with short-term debt and total debt ratios. This implies that (1) Growing companies and companies with high levels of tangible assets tend to use short-term debt rather than long-term debt. (2) Large and profitable companies are less likely to use short-term debt and tend to use less debt overall.

\section{Introduction}

The main purpose of this study is to examine the determinants of the capital structure (leverage) and the debt maturity structure of the industrial companies in Amman Stock Exchange (ASE) over the period (2001-2005).

The corporate capital structure literature contains many papers that examine the nature and the determinants of corporate capital structure. Following the classical work of Modigliani and Miller's classical paper (1958), which argued that the value of a company is independent from its capital structure, the theoretical and empirical analysis of financing patterns have been extended to incorporate additional factors such as taxes, bankruptcy costs, agency costs, and asymmetric information issues.

Moreover, the empirical literature identifies specific factors that may affect a firm's optimal capital structure. Some papers examined the determinants of capital structure include Harris and Raviv (1991), Rajan and Zingales (1995), Bevan and Danbolt (2000), Omet and Nobanee (2001), Huang and Song (2002), Antonion et al., (2002), Caesar, and Holmes, (2003), Chen, (2004), Hall, et al., (2004) and Buferna, et al., (2005).

Relative to the above, the primary objective of this study is to provide answers to the following questions:

1. What is the capital structure of Jordanian industrial companies?

2. Is the explanatory power of capital structure theories (determinants) applicable to Jordanian companies?

3. How the Jordanian managers of the industrial companies choose appropriate amount of debt for their firms?

4. How the Jordanian managers of the industrial companies choose between short term and long-term debt? 
This study was selected for many reasons:

1. Most capital structure studies were from developed countries, such as, Bevan and Danpolt (2002) examined the determinants of The capital structure in UK, Antoniou et al., (2002), examined the determinants of Corporate Capital Structure: Evidence from European Countries, Booth et al., (2001) examined the Capital structures in Developing Countries, Gleason, et al., (2000). examined the Interrelationship between Culture, Capital structure, and Performance: Evidence from European Retailers, Huang and Song (2002), examined the determinants of capital structure: Evidence from China, and Deesomsak, et al., (2004) examined the determinants of capital structure: evidence from the Asia Pacific region.

2. There were few studies from develop countries, such as, Pandey, M., (2001), examined the Capital structure and the firm characteristics: evidence from Indian, Sukkari (2003) analyzed the determinants of the capital structure for Kuwait companies, and Buferna et al., (2005) investigated the determinants of capital structure of Libyan private and public companies.

3. The industrial sector in Jordan is one of the vital economic sectors, which are attractive to investors. The industrial sector in Jordan contributes around 24\% from Gross Domestic Product (GDP) (Central Bank of Jordan, annual report, 2004, pp: 20-25).

4. This study attempts to fill the gap by analysing a capital structure evidence from Jordan, where Jordan differs from the developing countries previously studied. It has financial markets that have been ranked as one of the best among the emerging markets according to Standard and Poors (S\&P) indexes. With a 30\% growth, Amman Stock Exchange (ASE) was the fifth in term of performance among the other emerging markets included in (S\&P) indexes during 2003, Annual Report, 2004, Amman, Jordan, pp: 36-37).

Also, this study provides further evidence of the capital structure theories pertaining to under developing countries and examines the explanatory power of capital structure theories (determinants) applicable to Jordanian companies and how the Jordanian managers of the industrial companies choose appropriate amount of debt for their firms.

The current study is divided into four sections:

Section 1 provides a background and a review of the literature. Research methodology and data description are provided in section 2 , in which the sample and data specification are given, the proxies and initial tests are specified as well. Section 3 presents the expected results and analysis. The empirical tests with a summary of the results and its implications were presented in section 4 . 


\section{Background and Literature Review}

The theory of capital structure is closely related to the firm's cost of capital. Capital structure is the mix of the long-term sources of funds used by the firm. The primary objective of capital structure decisions is to maximize the market value of the firm through an approprate mix of long-term sources of funds. This mix, called the optimal capital structure, will minimize the firm's overall cost of capital. However, there are arguments about whether an optimal capital structure actually exist. The arguments focus on whether a firm can, in reality, affect its valuation and its cost of capital by varying the mixture of the funds used (Besley and Brigham, 2000, p. 458, Ross et al., 2002, p. 390).

Also, it is important to examine the capital structure of companies because it affects company's real decisions about employment, production, and investment (Harris and Raviv, 1991).

Modern capital structure theory began by Modigliani and Miller's classical paper (1958) which led to the development of a large number of theoretical and empirical papers. These papers examine the capital structure of choosen listed companies. The main proposition of this work is that, under a number of restrictive assumptions, the value of a company is independent from its financial structure. These assumptions include the absence of taxes, transactions and bankruptcy costs, equality of lending and borrowing rates and finally the independence of the productive activities of the company from its financing decisions.

Following the classical work of Modigliani and Miller (1958) which argued that the value of a company is independent from its financial structure, the theoretical and empirical capital structure studies, have been extended to incorporate additional factors, such as taxes, bankruptcy cost, agency costs and symmetric information issues.

Some of the main studies that examined the determinants of the capital structure include Myers (1984), Titman and Wessels (1988), Harris and Raviv (1991), Rajan and Zingales (1995), Bevan and Danbolt (2000) Booth et al., (2001), Huang and Song (2002), Antonion et al., (2002), Caesar, and Holmes, (2003), Chen, (2004), Hall, et al., ( 2004) and Buferna et al., (2005).

According to the above studies, the main determinants of the capital structure are: size of the company, tangibility, profitability, growth opportunities, short-term debt and long-term debt.

Both theoretical and empirical capital structure studies have generated many results that attempt to explain the determinants of capital structure. As a result 
of these studies, some broad categories of capital structure determinants have emerged.

Titman and Wessels (1988), and Harris and Raviv (1991), however, point out that the choice of suitable explanatory variables is potentially continues.

To identify which of the capital structure theories is relevant in the industrial companies in Amman Stock Exchange (ASE), the current study concentrates on five key variables which were identified in studies by Harris and Raviv (1991), Rajan and Zingales (1995), Bevan and Danbolt (2000), Omet and Nobanee (2001), Huang and Song (2002), Antonion et al., (2002), Cassar, and Holmes, (2003), Chen, (2004) and Buferna, et al., (2005). The selected explanatory variables are: size, tangibility, profitability, long-term debt and short-term debt. In addition, the financial structure of companies has divided into three parts:

First: a number of researchers investigated the determinants of the financing patterns (debt / equity ratios) of companies. For example: Harris and Raviv (1991), Rajan and Zingales (1995) and Omet and Nobanee (2001), argued that larger firms tend to be better and more diversified than small firms. In other words, they found that larger firms hold more debt in its capital structure than small firms. They argued that larger firms tend to have more long-term debt because of shareholder/lender conflict. This hypothesis has been well supported by the empirical evidence by Rajan and Zingales (1995). As well as, they found a positive relationship between leverage ratios and company size.

Second: some researchers investigated the determinants of the financing patterns on economic growth. For example: Myers (1984) argued that due to information asymmetries, economic with high leverage ratios might have the tendency to undertake countries activities to the interest of debt holders. Therefore, it can be argued that companies with high growth rate tend to have low leverage ratios. The empirical evidence regarding the relationship between leverage ratios and economic growth is mixed. Titman and Wessels (1988), Chung (1993) found a negative relationship.

Third: some researchers investigated the determinants of the financing patterns on the performance of companies within and across countries. For example: Bevan and Danpolt (2002) examined the determinants of the capital structure in UK, Antoniou, et al., (2002), examined the Determinants of Corporate Capital Structure: Evidence from European Countries, Booth, et al., (2001) examined the Capital structures in Developing Countries, Gleason, et al., (2000) examined the Interrelationship between Culture, Capital structure, and Performance: Evidence from European Retailers, Huang and Song (2002) examined the determinants of capital structure: Evidence from China, Cassar, and Holmes, (2003), examined the determinants of capital structure and 
financing of SMEs: Australian evidence and Chen, J., (2004), examined the determinants of capital structure of Chinese-listed companies.

Regarding the above studies, Bevan and Danbolt (2002) point out that capital structure studies examining the determinants of leverage based on total debts may disguise the significant differences between long-term and short-term debt, this study decompose debt into long-term and short-term debt. The debt ratio are: total debt to total assets, short-term debt to total assets and long-term debt to total debts. On the other hand Bevan and Danbolt (2002) report that size of the firm is found to be negatively related to short-term debt and positively related to long-term debt. Also they found that the more profitability firms should hold less debt, because high levels of profits provide a high level of internal funder.

Huang and Song (2002) have investigated the determinants of capital structure of companies in China, using firm level panel data, the mean leverage ratios and the mean ratios of long-term debt to total debt. They found a significant positive relationship between leverage ratios and the firm size.

Antonion et al., (2002) found that the capital structure decisions of firms were not only affected by its own characteristics but also by its surrounding environment. The surrounding environment may effect the firm's capital structure for different reasons, such as the deterioration or the improvment in the state of economy, the existance of a stock market and the size of a firm for its leverage ratio.

Omet and Nobanee (2001) examined the capital structure of listed industrial companies in Jordan. Using firm level panel data, the mean leverage ratios and the mean ratios of long term debt to total debt are calculated during the time period 1978-1998. Based on the statistical analysis, they found that company size and retained earnings divided by total assets are significant determinants of leverage. Furthermore, it was found that fixed assets to total assets and total assets are the only significant determinant factors of the debt ratios.

The current study differs from Omet and Nobanee (2001), as far as, variables identified, period of this study and number of companies listed in (ASE). The selected explanatory variables in this study are: size, tangibility, profitability, long-term debt and short-term debt, but explanatory variables in Omet and Nobanee's study are: Age of company, cash flows, size, growth rate and long-term debt and short-term debt.

Sukkari (2003) analyzed the determinants of the capital structure for Kuwait companies during the time period 1996-2001. Based on company level data, the mean total leverage ratio and the mean long-term debt to total debt are calculated. Based on the empirical results, it found that the leverage ratios werw 
low and that company size and company profitability were the most important determinants of leverage.

Buferna, et al., (2005) investigated the determinants of capital structure of Libyan private and puplic companies utilising data from 1995 to 1999. Debt was decomposed into three categories: short-term, long-term and total debt. The results indicate that profitable Libyan companies were externally financed and prefer short-term debt sources. The main puplic companies use both short-term and long-term debt. Growing companies tend to rely on their internal funds and large companies tend to have higher leverage.

To identify which of the capital structure theories is relevant to the industrial companies in Amman Stock Exchange (ASE), the current study concentrates on five key variables identified in studies by Harris and Raviv (1991), Rajan and Zingales (1995), Bevan and Danbolt (2000), Omet and Nobanee (2001), Huang and Song (2002), Antonion et al., (2002), Chen, (2004) and Buferna, et al., (2005). The selected explanatory variables are: size, tangibility, profitability, long-term debt and short-term debt. These five explanatory variables are identified as important factors in the developed and developing countries. For example: Both Bevan and Danbolt (2002) and Buferna, et al., (2005) studies investigate the determinants of the capital structure in UK and Libya. Bevan and Danpolt (2002) examined the determinants of the capital structure in UK based on total debts may disguise the significant differences between long-term and short-term debt, this study decompose debt into long-term and short-term debt. The debt ratio is: total debt to total assets, short-term debt to total assets and long-term debt to total assets. On the other hand Bevan and Danbolt (2002) reported that size of the firm was found to be negatively related to short-term debt and positively related to longterm debt. Also they found that the more profitable firms should hold less debt, because high levels of profits provide a high level of internal founder.

The other study by Buferna, et al., (2005) investigated the determinants of capital structure of Libyan private and public companies utilising data from 1995 to 1999. Debt is decomposed into three categories: short-term, long-term and total debt. The results indicated that profitable Libyan companies were externally financed and prefer short-term debt sources. These studies used a cross sectional OLS regression for testing their results. The current study also will use the same Quantitative methods of analysing data used by Bevan and danpolt (2002) and by Buferna, et al., (2005).

The present study attempts to reduce the gap of capital structure studies which are based on evidence from developed and developing countries, because 
most capital structure studies to date are based on evidence from developed countries, but there are few studies that provide evidence from developing countries.

Finally, the current study investigates determinants of the capital structure (leverage) and the debt maturity structure of the Jordanian industrial companies over the period (2001-2005). Therefore, the final results could be very important for both private and public scoters in Jordan. Also, it provides further evidence of the capital structure theories which pertain to developing countries. It examines the explanatory power of capital structure theories (determinants) applicable to Jordanian companies and how the Jordanian managers of the industrial companies choose appropriate amount of debt for their firms.

\section{Methodology and Data Description}

\subsection{Data}

The sample of this study consists of all Industrial companies listed in the Amman Stock Exchange (ASE) for 2005, totaling 30 companies (Appendix 1). The selected companies should met the following conditions:

1- Industrial company's shares have been traded in the Amman Stock Exchange in the period (2001-2005).

2- Trading has not been interrupted in those companies' shares which have not been merged or liquidated throughout the period of study.

3- Data of financial structure have been available about those companies throughout the period of study.

The study depended on the following sources for collecting the needed data:

1- Annual reports issued by Jordanian industrial companies.

2- Annual report issued by Amman Stock Exchange.

3- Annual reports issued by the Central Bank of Jordan.

4- Some statistics issued by the Jordanian Department of Statistics (DOS).

\subsection{Quantitative Methods of Analysing Data}

To estimate regression model, the Ordinary Least Squares (OLS) was used to examine the determinants of the capital structure (leverage) and the debt maturity structure of the industrial companies in Amman Stock Exchange (ASE) over the period (2001-2005). 


\subsection{Explanatory Variables}

\section{3.1. Dependent Variables}

Independent and dependent variables of the current study have been determined according to the results reached by previous studies and how far data have been available for measurement purposes. There are two measures used to identify the dependant variables. These measures are:

1- Leverage ratio (Lev 1): which is measured by total debts to total assets. It is argued by Harris and Raviv (1991), Rajan and Zingales (1995), Bevan and Danbolt (2000), Omet and Nobanee (2001), Huang and Song (2002), Antonion, et al., (2002), Chen, (2004) and Buferna, et al., (2005). This ratio demonstrates the relationship between total liabilities and total assets. Selecting this measure is attributed to the fact that using debts for funding purposes within the financing structure constitutes an incentive and target for many companies to increase their return on investment. Meanwhile, the capital structure policy involves venture and returns trade offs simply because using debt extensively increases the risks faced by the industrial company, but amplifies total invested funds and expected return.

2- $\frac{L T D}{T D}=$ Long-term debts/total debts: It is measured by Long-term debts/ total debts. It has been argued by Harris and Raviv (1991), Rajan and Zingales (1995), Bevan and Danbolt (2000), Omet and Nobanee (2001), Huang and Song (2002), Antonion, et al., (2002), and Buferna, et al., (2005).

This ratio is intended to measure the risks to which the industrial company is subjected through depending on money borrowed for financing its assets. A lower index in this regard means that the industrial company depends on borrowed money for financing its assets, thereby exacerbating capital risks.

\subsubsection{Independent Variables}

Independent variables of the study on which data were collected include the following:

1- Company size: it is measured by the natural logarithm of total assets. It is argued by Titman \& Wessels (1988) Huang and Song (2002) and Antoniou, et al., (2002); They found a significant positive relationship between leverage ratios and size of the firm .Industrial company size has been selected as an independent variable because industrial companies with large total assets are capable of diversifying their investments and subsequently, are less vulnerable for bankruptcy and insolvency (Rajan and Zingales, 1995). Moreover, the cost of funding for these companies will be lower, and the debt ratio within the 
financing structures of major banks is expected to be larger than equity . It has been indicated by various studies that there is a positive relationship between a company size and leverage which, therefore, reflects positively on such company's profitability (Booth, et al., 2001).

As a result, the relationship between leverage ratio (Lev 1) and size of the firm is expected to be positive. Also, it is expected a positive relationship between $\frac{L T D}{T D}$ (Long-term debts / total debts) and size of the firm.

2- Tangibility fixed assets (Tang): it is measured by fixed assets divided total assets. Tang $=\frac{F A}{T A}$. It has been argued by Harris and Raviv (1991), Rajan and Zingales (1995), Bevan and Danbolt (2000), Omet and Nobanee (2001), Huang and Song (2002), Antonion, et al., (2002), and Buferna, et al., (2005).

They found a significant positive relationship between leverage ratios and tangibility of the firm.

As a result, the relationship between leverage ratio (Lev 1) and Tangible fixed assets (Tang) is expected to be positive. Also, it is expected the positive relationship between $\frac{L T D}{T D}$ (Long-term debts / total debts) and tangible fixed assets (Tang).

3- Profitability ratio: It is measured by dividing earning before interest and tax by book value of total assets. It is argued by Harris and Raviv (1991) that companies with strong financial position can have relatively easier access to cheaper debt and hence to invest more. There is complementary effect between Profitability and total debts (total liabilities). This ratio is measured by Rajan and Zingales (1995), Bevan and Danbolt (2000), Huang and Song (2002), Antonion, et al., (2002), and Buferna, et al., (2005). It is a significant and a negative relationship between leverage ratios and profitability of the firm. So, the relationship between leverage ratio (Lev 1) and profitability is expected to be negative. In other words, increased industrial company's earning before interest and tax will enhance industrial company's capability of repaying liabilities and financing assets out of its own sources. Thus, the industrial company will be in a better position to compete with other industrial companies, and there will be higher expectations concerning the industrial company's ability to benefit from the advantages of relying on debts, thereby yielding positive impacts (Keister, 2000).

4- Long-term debt to total assets which is measured by long-term debt to total assets. $(\mathrm{LTD} / \mathrm{TA})=\frac{\text { LongTermDebt }(\text { LTD })}{\text { TotalAssets }(T A)}$ 
It is based on Bevan and Danbolt (2002) and Omet and Nobanee (2001). They found a positive relationship between leverage ratio (Lev 1) and long-term debt and a positive relationship between $\frac{L T D}{T D}$ (Long-term debts/total debts) and long-term debt of the firm. This ratio is intended to measure assets which are financed through long-term debts. There is no doubt that reliance on longterm debts to finance assets involves many risks. However, it is interesting to note that if these debts are properly used, they will generate profitability in favour of the industrial company and will maximize the owner equity.

As a result, the relationship between leverage ratio (Lev 1) and Long-term debt is expected to be positive. Also, a positive relationship is expected between $\frac{L T D}{T D}$ (Long-term debts / total debts) and Long-term debt.

5- Short-term debt to total assets which is measured by short-term debt to total assets.

$$
(\mathrm{STD} / \mathrm{TA})=\frac{\text { ShortTermDebt }(\text { STD })}{\text { TotalAssets }(T A)}
$$

It is based on Bevan and Danbolt (2002) and Omet and Nobanee (2001). They found a positive relationship between leverage ratios and short-term debt of the firm. And they found a negative relationship between $\frac{L T D}{T D}$ (Long-term debts/total debts) and Short-term debt. This ratio is intended to measure the extent of using short-term debts for financing assets. These debts are usually used for financing working capital and other short-term liabilities. This relationship tends to have an impact on leverage in the sense that short-term debts should be repaid in a period not exceeding one fiscal year. It is, therefore, expected that this relationship will have a positive impact in case of the industrial company's capability of and compliance with repaying such debts during the relevant period.

As a result, the relationship between leverage ratio (Lev 1) and short-term debt is expected to be positive. Also, the negative relationship is expected between $\frac{L T D}{T D}$ (Long-term debts/total debts) and short-term debt.

Table (1) summarizes the statistics for the various explanatory dependent variables (Lev 1 and LTD/TA) for the entire sample of Jordanian industrial companies. From these results, it can be seen that Jordanian industrial companies (Lev1) have a low mean of 0.3034 . This ratio is quite low compared to those of Germany (0.73), Japan (0.69), United States (0.58), and United 
Kingdom (0.54), reported by Rajan and Zingales (1995). Additionally, this ratio is almost similar to that of leverage in Kuwaiti companies which reached (0.327) (Sukkari, 2003). According to low of the ratio (Lev 1 and LTD / TA) compared with developed countries the Central Bank of Jordan has adopted policies aimed at stimulating the local capital market, particularly where longterm project finance is required. A number of banks have established mutual funds. In addition to long-term instruments, e banking, securitization, shortselling and treasury stocks are being introduced in some banks. ( $38^{\text {th }}$ Annual Report for 2001, Central Bank of Jordan, pp: 36-37).

Table 1. Descriptive Statistics (Dependent Variable) (2001-2005).

\begin{tabular}{|l|c|c|}
\hline & Lev1* & LTD / TD** \\
\hline Mean & 0.3034 & 0.1539 \\
\hline Maximum & 1.778 & 0.8343 \\
\hline Minimum & 0.0250 & -0.1369 \\
\hline Standard Deviation & 0.2712 & 0.2390 \\
\hline
\end{tabular}

(*) Lev1 is equal to total liabilities divided by total assets.

(**) LTD / TA is equal Long-term debt divided by total debts.

However, the second index LTD/TD, i.e. result of dividing long-term debt by total debts, have a low mean of (0.1539) compared to leverage in Germany that reached 0.55 and Kuwaiti companies, which reached 0.35 (Sukkari, 2003). Apparently the standard deviation for both Lev 1 and LTD/TD indices are approximately 0.27 and 0.23 these ratios are similar for both ratios because the Jordanian industrial companies depend on its financing on equity instead of debts.

Table No. (2) summarizes the statistics for the various explanatory independent variables for the entire sample of Jordanian industrial companies. From these results, it can be seen that profitability of Jordanian industrial companies approximately (0.058). The tangibility rate on average is 0.3958 , a long term debt is 0.0749 and a short term debt is 0.2284 . Table No. (2) shows the descriptive statistics (Independent Variables) (2001 - 2005).

Table 2. Descriptive Statistics (Independent Variables) (2001- 2005).

\begin{tabular}{|l|c|c|c|}
\hline & Mean & Std. Deviation & N \\
\hline Total assets * & 7.085 & 0.660 & 150 \\
\hline Tangibility ** & 0.395 & 0.203 & 150 \\
\hline Profitability*** & 0.0586 & 0.083 & 150 \\
\hline Long Term Debts**** & 0.0749 & 0.127 & 150 \\
\hline Short Term Debts***** & 0.228 & 0.227 & 150 \\
\hline
\end{tabular}

(*) Size is equal to the natural logarithm of total assets

(**) Tangibility fixed assets (Tang) is measured by fixed assets divided total assets.

$(* * *)$ Profitability ratio is measured by earning before interest and tax divided by book value of total assets.

$(* * * *)$ Long-term debt to total assets is measured by long-term debt to total assets,

$(* * * * *)$ Short-term debt to total assets is measured by short-term debt to total assets. 
Table No. (3) presents a correlation matrix of the leverage (Lev 1) and explanatory variables. From these results, it can be seen that total assets, tangibility, long-term debt, short-term debt are positively related to leverage (Lev 1), while profitability has a negative relationship with leverage (Lev 1), This means, Jordanien industrial companies are depending on equity for investment financing. So it is required to increase their debts, especially long term debts and decrease their short-term debts.

Table 3. A Correlation Matrix of the Leverage (Lev 1) and Explanatory Variables.

\begin{tabular}{|c|c|c|c|c|c|c|}
\hline & LEV(1) & $\begin{array}{c}\text { Total } \\
\text { Assets }\end{array}$ & $\begin{array}{c}\text { Fixed } \\
\text { Assets }\end{array}$ & Profitability & $\begin{array}{c}\text { Long Term } \\
\text { Debts }\end{array}$ & $\begin{array}{c}\text { Short Term } \\
\text { Debts }\end{array}$ \\
\hline LEV(1) & 1.000 & & & & & \\
\hline Total Assets & 0.253 & 1.000 & & & & \\
\hline Tangibility & 0.419 & 0.049 & 1.000 & & & \\
\hline Profitability & -0.496 & 0.067 & -0.340 & 1.000 & & \\
\hline Long Term Debts & 0.548 & 0.403 & 0.380 & -0.350 & 1.000 & \\
\hline Short Term Debts & 0.883 & 0.075 & 0.286 & -0.394 & 0.091 & 1.000 \\
\hline
\end{tabular}

Table No. (4) presents a correlation matrix of the LTD/TD and explanatory variables.

The results show that total assets, tangibility, long-term debt, are positively correlated with LTD/TD, while short term debts has a negative correlation with LTD/TD). This means that Jordanian industrial companies are depending on equitiy for financing their investments, where the equity of Jordanian industrial companies represent about $70 \%$ from their total financing investments.

Table 4. Correlation Matrix of the LTD / TD and Explanatory Variables.

\begin{tabular}{|c|c|c|c|c|c|}
\hline & LTD / TD & $\begin{array}{c}\text { Total } \\
\text { Assets }\end{array}$ & $\begin{array}{c}\text { Fixed } \\
\text { Assets }\end{array}$ & $\begin{array}{c}\text { Long Term } \\
\text { Debts }\end{array}$ & $\begin{array}{c}\text { Short Term } \\
\text { Debts }\end{array}$ \\
\hline LTD / TD & 1.000 & & & & \\
\hline Total Assets & 0.434 & 1.000 & & & \\
\hline Fixed Assets & 0.427 & 0.049 & 1.000 & & \\
\hline Long Term Debts & 0.933 & 0.403 & 0.380 & 1.000 & \\
\hline Short Term Debts & -0.001 & 0.075 & 0.286 & 0.091 & 1.000 \\
\hline
\end{tabular}

Based on the above discussion it can form the hypotheses as follows:

1. Size

Ho1: There is a significant positive relationship between leverage ratios and size of the firm.

Ho2: There is a significant positive relationship between LTD/TD and size of the firm. 
2. Tangibility

Ho3: There is significant positive relationship between leverage ratios and tangibility of the firm.

Ho4: There is a significant positive relationship between LTD/TD and tangibility of the firm.

\section{Profitability}

Ho5: There is a significant negative relationship between leverage ratios and profitability of the firm.

\section{Long-term debt}

Ho6: There is a positive relationship between leverage ratios and long-term debt.

Ho7: There is a positive relationship between LTD / TD and long-term debt.

\section{Short-term debt}

Ho8: There is a negative relationship between leverage ratios and short-term debt of the firm.

Ho9: There is a negative relationship between LTD / TD and short-term debt of the firm.

To test the above hypotheses the following regression model can be estimated as follows:

(1) Lev (1) $=\mathrm{c}+\mathrm{b} 1$ size $+\mathrm{b} 2$ Prof $+\mathrm{b} 3$ Tang $+\mathrm{e}$

(2) $\operatorname{Lev}(1)=\mathrm{c}+\mathrm{b} 1 \frac{L t d}{T A}+\mathrm{b} 2 \frac{S T D}{T A}+\mathrm{e}$

Where:

Lev (1) $=$ Leverage (1) $\frac{\text { Total Liabilitie }}{\text { Total Assets }}$

$\mathrm{C}=$ constant factor

$\mathrm{b}=$ the regression coefficient which needs to be tested

Size $=$ the size of the company

Prof $=$ profitability

Tang $=$ Tangibility

Ltd $=$ long - term debt

$\mathrm{TA}=$ total assets 
$\mathrm{STD}=$ short - term debt

$\mathrm{e}=$ the random errors

(3) $\frac{L T D}{T D}=\mathrm{c}+\mathrm{b} 1 \frac{L t d}{T A}+\mathrm{b} 2 \frac{S T D}{T A}+\mathrm{b} 3 \frac{F A}{T A}+\mathrm{b} 4 \log \mathrm{TA}+\mathrm{e}$

Where:

$\frac{L T D}{T D}=$ Long-term debts / total debts

$\mathrm{C}=$ constant factor

$\mathrm{b}=$ the regression coefficient which needs to be tested

$\frac{L t d}{T A}=$ Long - term debt $\mathrm{s} /$ total assets

$\frac{S T D}{T A}=$ Short - term debts $/$ total assets

$\frac{F A}{T A}=$ Fixed assets / total assets

$\log \mathrm{TA}=\log$ total assets

$\mathrm{e}=$ the random errors

\section{Results and Discussion}

Table (5) shows the results of regression analysis of the (Lv1) model used to explain determinants of the capital structure of Jordanian industrial companies.

Table 5. Regression Results of Lev1 (2001-2005).

\begin{tabular}{|c|c|c|c|c|}
\hline Variable & Sig * & Coefficient & t- statistic & $\begin{array}{c}\text { collinearity } \\
\text { statistic (vif) }\end{array}$ \\
\hline Constant & 0.006 & -0.535 & -0.802 & - \\
\hline TA ( Log ) & $<0.001$ & 0.110 & 4.126 & 1.010 \\
\hline Tang & $<0.001$ & 0.349 & 3.791 & 1.137 \\
\hline Prof & $<0.001$ & -1.372 & -6.144 & 1.140 \\
\hline LTD & $<0.001$ & 1.000 & - & -1.008 \\
\hline STD & $<0.001$ & 1.000 & - & 1.088 \\
\hline F-Statistic & $<0.001$ & 30.870 & - & - \\
\hline
\end{tabular}

* Significant

Adjusted $\mathrm{R}^{2}$

DW. 
As expected, the coefficient estimates of TA, Tangibility (Tang), LTD and STD are significant and positive relationship (Table 3.1). This result is similar to those results that are obtained by Harris and Raviv (1991), Rajan and Zingales (1995), Bevan and Danbolt (2000), Omet and Nobanee (2001), Huang and Song (2002), Antonion, et al., (2002), and Buferna, et al., (2005). In other words, large Jordanian industrial companies are highly leveraged because this might be due to the fact that they are able to reduce the risk of bankruptcy and their greater degree of diversification enables them to obtain debt more easily than smaller companies.

As well as, these results are similar to those of the expected hypotheses:

Ho1: There is a significant positive relationship between leverage ratios and size of the firm. Because industrial companies with large total assets are capable of diversifying their investments and subsequently, are less vulnerable for bankruptcy and insolvency (Rajan and Zingales, 1995). Moreover, the cost of funding for these companies will be lower, and the debt ratio within the financing structures of major banks is expected to be larger than equity.

Ho3: There is a significant positive relationship between leverage ratios and Tangibility of the firm. This relationship is based on the argument that fixed assets can be used as collateral and bargaining power in obtaining long-term debt (Hall, et al., 2004).

Ho6: There is a positive relationship between leverage ratios and long-term debt.

It is due for larger firms to hold more debt in its capital structure than small firms. They are argued that larger firms tend to have more long-term debt because of shareholder lender conflict. This hypothesis has been well supported by the empirical evidence (Rajan and Zingales, 1995).

Ho8: There is a positive relationship between leverage ratios and short-term debt of the firm. This relationship tends to have an impact on leverage in the sense that short-term debts should be repaid in a period not exceeding one fiscal year. It is, therefore, expected that this relationship will have a positive impact in case of the industrial company's capability of and compliance with repaying such debts during the relevant period. From Table (5), there is a significant negative relationship between leverage ratio (Lev 1) and Profitability of the Jordanian industrial companies. This result is similar to those results that are obtained by Rajan and Zingales (1995), Bevan and Danbolt (2000), Huang and Song (2002), Antonion, et al., (2002), and Buferna, et al., (2005). Also, these results are similar to those of the expected hypothesis (Ho5).

Ho5: There is a significant negative relationship between leverage ratios and Profitability of the firm. This relationship due to increased industrial company's 
earning before interest and tax will enhance industrial company's capability of repaying liabilities and financing assets out of its own sources. Thus, the industrial company will be in a better position to compete with other industrial companies, and there will be higher expectations concerning the industrial company's ability to benefit from the advantages of relying on debts. Thus, the researchers believe that Profitability has a negative relationship with leverage (Lev 1), because Jordanian industrial companies are depending on debts for investment financing. So it is required to decrease their debts, especially long term debts and increase their ownership. Table (5) also shows that all used variables are randomly distributions. The absence of any significant correlation in the estimated error terms $(\mathrm{DW}=2.023)$ and the value of the F-Statistic (30.870), we can conclude that based on the time period (2000 - 2004), both TA, Tangibility (Tang), LTD and STD are significant and positive relationship of the capital structure of the Jordanian industrial companies.

Table (6) shows the results of regression analysis of the $\frac{L t d}{T A}=$ Long-term debts / total assets model used to explain determinants of the capital structure of Jordanian industrial companies.

Table 6. Regression Results of $\frac{L t d}{T A}=$ Long-term Debt s / Total Assets (2001 - 2005).

\begin{tabular}{|l|c|c|c|c|}
\hline Variable & Sig * & Coefficient & t- statistic & collinearity statistic (vif ) \\
\hline (Constant) & 0.003 & -0.235 & -3.053 & - \\
\hline Total Assets & 0.002 & 0.033 & 3.114 & 1.010 \\
\hline Fixed Assets & $<0.001$ & 0.156 & 4.377 & 1.137 \\
\hline Long Term Debts & $<0.001$ & 1.603 & 26.819 & 1.140 \\
\hline Short Term Debts & $<0.001$ & -0.131 & -4.441 & $1.008-$ \\
\hline F-Statistic & $<0.001$ & 30.870 & - & - \\
\hline
\end{tabular}

* Significant at the 0.01 level

Adjusted $\mathrm{R}^{2} \ldots \ldots \ldots .0 .893$

DW....................1.034

As expected, the coefficient estimates of TA, Tangibility (Tang) and longterm debts are significant and positive relationships. (Table 6). This result is similar to those results that are obtained by Harris and Raviv (1991), Rajan and Zingales (1995), Bevan and Danbolt (2000), Omet and Nobanee (2001), Huang and Song (2002), Antonion, et al., (2002), and Buferna, et al., (2005).

As well as, these results are similar to those of the expected hypotheses:

Ho2: There is a significant positive relationship between LTD/TD and size of the firm. It is due to that large firms to hold more debt rather than small firms, because large firms have higher debt capacity. This relationship is argued 
by Bevan and Danbolt (2000), Omet and Nobanee (2001), Huang and Song (2002), Antonion, et al., (2002), and Buferna, et al., (2005).

Ho4: There is a significant positive relationship between LTD / TD and Tangibility of the firm. This relationship due to firms with high levels of tangible assets will be in a position to provide collateral for debts. So the companies with high levels of tangible assets are less likely to default and will take on relatively more debt resulting in a positive relationship between LTD / TD and Tangibility. (Titman and Wessels, 1988; Rajan and Zingales, 1995).

Ho7: There is a positive relationship between LTD/TD and long-term debt

This relationship due to size of the firm that large firms are able to hold more debt rather than small firms, because large firms have higher debt capacity. This relationship argued by Bevan and Danbolt (2000), Omet and Nobanee (2001), Huang and Song (2002), Antonion, et al., (2002), and Buferna, et al., (2005).

In other words, large Jordanian industrial companies are highly leveraged because this might be due to the fact that they are able to reduce the risk of bankruptcy and their greater degree of diversification enables them to obtain debt more easily than similar companies. Table (6) shows also, there is a significant negative relationship between Long-term debts/total assets and shortterm debts of the Jordanian industrial companies. This result is similar to those results that are obtained by, Rajan and Zingales (1995), Bevan and Danbolt (2000), Huang and Song (2002), Antonion, et al., (2002), and Buferna, et al., (2005).

Also, these results are similar to those in the expected hypothesis' (Ho9)

Ho9: There is a negative relationship between LTD/TD and short-term debt of the firm. This relationship based by Bevan and Danbolt (2002) report that size of the firm is found to be negatively related to short-term debt and positively related to long-term debt. Also they are finding that the more profitability firms should hold less debt, because high levels of profits provide a high level of internal founder.

As well as, the facts that all used Variables are randomly distributions. the absence of any significant correlations in the estimated error terms $(\mathrm{DW}=1.034)$ and the value of the F-Statistic (30.870), we can conclude that based on the time period (2000-2004), both TA, Tangibility (Tang) and long-term debts are significant positive relationship of the capital structure of the Jordanian industrial companies.

$\mathrm{R}^{2}$ for the first index Lev1 is around 0.378 and $\mathrm{R}^{2}$ for the second index LTD/TA is around 0.893 . This means that independent variables that have been 
taken into consideration account for a high ratio of determinants of leverage and capital structure of Jordanian industrial companies.

\section{Summary and Conclusions}

The primary objective of capital structure decisions is to maximize the market value of the firm through an appropriate mix of long-term sources of funds. This mix, called the optimal capital structure, will minimize the firm's overall cost of capital. However, there are arguments about whether optimal capital structures actually exist. The arguments center on whether a firm can, in reality affect its valuation and its cost of capital by varying the mixture of the funds used (Besley and Brigham, 2000, p 458, Ross, et al., 2002, p. 390).

The corporate capital structure literature contains many papers that examine the nature and the determinants of corporate financial structure. Following the classical work of Modigliani and Miller's classical paper (1958), which argued that the value of a company is independent from its financial structure, the theoretical and empirical analysis of financing patterns have been extended to incorporate additional factors such as taxes, bankruptcy costs, agency costs, and asymmetric information issues.

The sample of this study consists of panel data for all industrial companies listed within the Amman Stock Exchange (ASE) for 2005, a total of 30 companies. This study attempts to reduce the gap by analysing a capital structure evidence from Jordan, where Jordan differs from the developing countries previously studied, as it has a financial market that has been ranked as one of the best among the emerging markets according to Standard and Poors (S\&P) Indexes. With a $30 \%$ growth, (ASE) was the fifth in term of performance among the other emerging markets included in (S\&P) indexes during 2003. The industrial sector in Jordan is one of the vital economic sectors, which are attractive to investors. The industrial sector in Jordan contributes around 24\% from Gross Domestic Product (GDP).

The findings of this study contribute towards a better understanding of financing behaviour in Jordanian industrial companies. Hypotheses, based on comparing the relationships between Leverage ratio (Lev 1), $\frac{L T D}{T D}$ ( Long-term debts / total debts) and five explanatory variables including size, tangibility, profitability, long-term debt and short-term debt. To test those relationships, it used regression analysis of the Leverage ratio (Lev 1$)$ and $\frac{L t d}{T A}$ model to explain determinants of the capital structure of Jordanian industrial companies on the time period (2001 - 2005). 
Those results are:

1. There is a significant positive relationship between Leverage ratio (Lev 1), $\frac{L T D}{T D}$ (Long-term debts / total debts) and size of the firm.

2. There is a significant positive relationship between Leverage ratio (Lev 1), $\frac{L T D}{T D}$ (Long-term debts / total debts) and tangibility of the firm.

3. There is a significant negative relationship between leverage ratios and Profitability of the firm.

4. There is a positive relationship between Leverage ratio (Lev 1), $\frac{L T D}{T D}$ (Long-term debts/total debts) and long-term debt.

5. There is a positive relationship between Leverage ratio (Lev 1) and shortterm debt of the firm.

6. There is a negative relationship between LTD/TD and short-term debt of the firm.

Also, the results show that Total assets, Tangibility, Long-term debt, are positively correlated with LTD/TD, while short-term debts has negatively correlated with LTD/TD. This means that Jordanian industrial companies are depending on equity for financing their investments, where the equity of Jordanian industrial companies represent about $70 \%$ from their total financing investments.

In other words, the results of this study show that large Jordanian industrial companies are highly leveraged because this might be due to the fact that they are able to reduce the risk of bankruptcy and their greater degree of diversification enables them to obtain debt more easily than smaller companies.

\section{References}

Amman Stock Exchange (ASE) (2004) Annual Report, 2004, Amman, Jordan, pp: 36-37.

Antoniou, A., Guney, Y. and Paudyal, K. (2002) Determinants of Corporate Capital Structure: Evidence from European Countries, University of Durham, Working paper, pp: 1-8.

Besley, S. and Brigham, E.F. (2000) Essentials of managerial finance, Twelfth edition, the Dryden press, USA, P. 458.

Bevan, A. and Danbolt, J. (2000) Dynamics in the Determinants of Capital Structure in the UK, University of Glasgow, Working paper, pp: 1-10.

Bevan, A. and Danbolt, J. (2002) Capital Structure and its Determinants in the UK- A Deco Positional Analysis, Applied Financial Economics 12: 159-170.

Booth, L., Aivazian, V., Demirguc-Kunt, A. and Maksimovic, V. (2001) Capital Structures in Developing Countries, The Journal of Finance, LVI: 87-130. 
Buferna, F., Bangassa, K. and Hodgkinson, L. (2005) "Determinants of Capital Structure: Evidence from Libya", University of Liverpool, Working Paper, pp: 2-7.

Central Bank of Jordan, (38 ${ }^{\text {th }}$ Annual Report for 2001, pp: 36-37).

Central Bank of Jordan, Annual Report, 2004, pp: 20-25.

Caesar, G. and Holmes, S. (2003) Capital Structure and Financing of SMEs: Australian Evidence", Journal of Accounting and Finance, 43: 123-147.

Chen, J. (2004) Determinants of Capital Structure of Chinese-listed Companies, Journal of Business Research, 57: 1341-1351.

Deesomsak, R., Paudyal, K. and Pescetto, G. (2004) The Determinants of Capital Structure: Evidence from the Asia Pacific Region, Journal of Multinational Financial Management, 14: 387-405.

Gleason, K., Mathur, L. and Mathur, I. (2000) The Interrelationship between Culture, Capital Structure, and Performance: Evidence from European Retailers, Journal of Business Research, 50: 185-191.

Hall, G., Hutchinson, P. and Michaelas, N. (2004) Determinants of the Capital Structures of European SMEs, Journal of Business Finance \& Accounting, 31: 711-728.

Harris, M. and Raviv, A. (1991) The Theory of Capital Structure, The Journal of Finance, 46: 297-355.

Huang, S. and Song, F. (2002) The Determinants of Capital Structure: Evidence from China, Working paper, The University of Hong Kong, pp: 2-7 .

Keister, L. (2000) Capital Structure in Transition: Financial Strategy in China's Emerging Economy, Working paper, The Ohio State University, pp: 7-15

Modigliani, F. and Miller, M. (1958) The Cost of Capital, Corporation Finance and the Theory of Investment, The American Economic Review, 48: 261-297.

Myers, S. (1984) The Capital Structure Puzzle, The Journal of Finance, 39: 575-592.

Omet, G. and Nobanee, H. (2001) The Capital Structure of Listed Industrial Companies in Jordan, Arabic Journal of Administrative Sciences, 8: 273-289.

Pandey, M. (2001) Capital Structure and the Firm Characteristics: Evidence from An Emerging Market, Indian Institute of Management Ahmedabad, Working paper, pp: 3-5.

Rajan, R. and Zingales, L. (1995) What Do Know About Capital Structure? Some Evidence from International Data, The Journal of Finance, 50: 1421-1460.

Ross, S.A., Westerfield, R.W. and Jaffe, J. (2002) Corporate Finance, McGraw - Hill, USA, P. 390.

Sukkari, A. (2003) "The Determinants of the Capital Structure in the Kuwaiti Capital Market", Master Thesis, The Hashemite University, Amman, Jordan, pp: 2-10.

Titman, S. and Wessels, R. (1988) The Determinants of Capital Structure Choice, The Journal of Finance, 43: 1-19. 


\section{Appendix (1)}

\begin{tabular}{|l|l|}
\hline & \multicolumn{1}{|c|}{ Company Name } \\
\hline 1 & Jordan Petroleum Refinery \\
\hline 2 & Jordan Dairy \\
\hline 3 & The Puplic Mining \\
\hline 4 & Arab Aluminium Industry /Aral \\
\hline 5 & Arab Pharmaceutical Manufacturing \\
\hline 6 & The Industrial Commercial \& Agricultural \\
\hline 7 & Arab Chemical Detergents Industries \\
\hline 8 & Jordan Tanning \\
\hline 9 & Arab Center For Pharm.\& Chemicals \\
\hline 10 & Jordan Poultry Processing \& Marketing \\
\hline 11 & Jordan Sulpho-Chemicals \\
\hline 12 & Jordan Ceramic Industries \\
\hline 13 & Pearl- Sanitary Paper Converting \\
\hline 14 & National Steel Industry \\
\hline 15 & Dar Al Dawa Development \& Investment \\
\hline 16 & The Arab Potash \\
\hline 17 & Union Chemical \& Vegetable Oil Industries \\
\hline 18 & Industrial Industries \& Match/Jimco \\
\hline 19 & National Poultry \\
\hline 20 & Jordan Rock Wool Industries \\
\hline 21 & Woolen Industries \\
\hline 22 & The Jordan Pipes Manufacturing \\
\hline 23 & Jordan Phosphate Mines \\
\hline 24 & The Jordan Cement Factories \\
\hline 25 & Jordan Paper \& Cardboard Factories \\
\hline 26 & General Investment \\
\hline 26 & Universal Chemical Industries \\
\hline 28 & Al-Januob Filters Manufacturing \\
\hline 29 & Jordan Chemical Industries \\
\hline
\end{tabular}




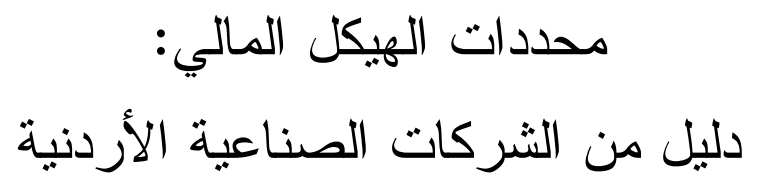

حسني علي خريوش وعلي حسني علي خريوش قسم العلوم المالية و المصرفية - كلية الاقتصاد الجامعة الهاشمبة- الزرقاء - المدلكة الأردنية الهاشمية و "محلل مالي - مركز جو اثا الاستشاري لتطوبير الأعمال الرياض - المدلكة العربية السعودية

khrawish@hu.edu.jo and Ali.Khraiwesh@gmail.com

المستخلص . قامت الدر اسة بفحص محددات الهيكل المالي للشركات

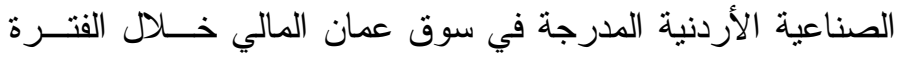

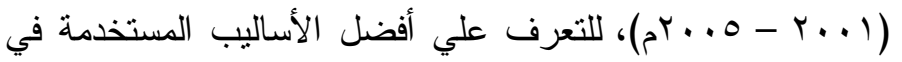

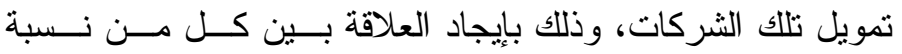

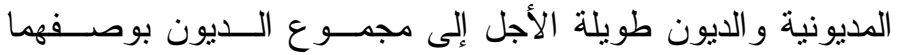

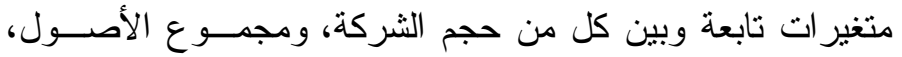

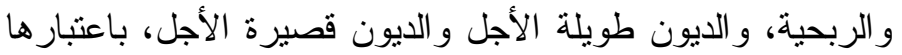

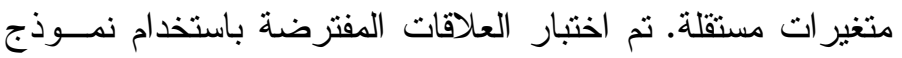
الانحدار الخطى المتعدد، وتوصلت الدراسة إلى وجود علاقة هامة

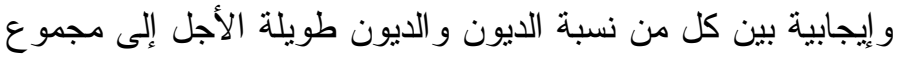

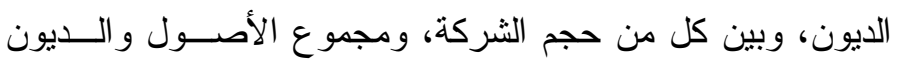

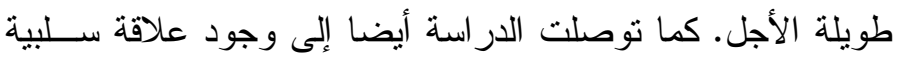

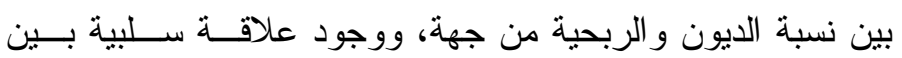
الديون طويلة الأجل إلى مجموع الديون و الديون قصيرة الأجل من لرنه

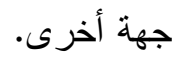


إضافة إلى ذلك فقد توصلت الدراسة إلى أن أغلبية الثركات

الصناعية الأردنية تعنمد في (• ٪\%) من تمويلها على حقوق الملكية،

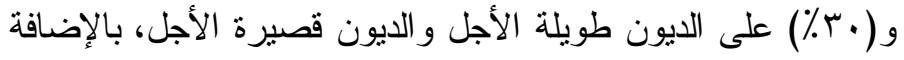
إلى أن أغلبية الثركات الصناعية الأردنية تعتمد على الديون قصبرة الإند

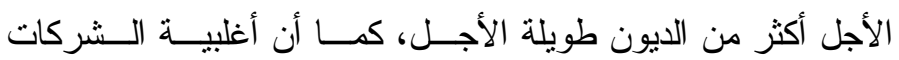

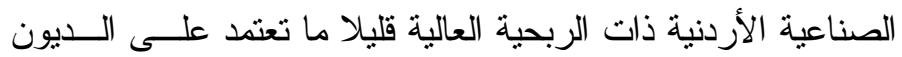
بصفة عامة. 